\title{
Growth, biomass, and chlorophyll-a and carotenoid content of Nannochloropsis sp. strain BJ17 under different light intensities
}

\section{Pertumbuhan, biomassa, dan konsentrasi pigmen klorofil-a dan karotenoid Nannochloropsis sp. strain BJ17 pada intensitas cahaya berbeda}

\author{
Muhammad Fakhri*, Nasrullah Bai Arifin, Anik Martina Hariati, Ating Yuniarti \\ Program Studi Budidaya Perairan, Fakultas Perikanan dan Ilmu Kelautan, Universitas Brawijaya \\ Jalan Veteran, Malang, 65145 \\ *E-mail: mfakhri@ub.ac.id
}

\begin{abstract}
Nannochloropsis sp. has been identified as sources of live feed and pigment in aquaculture. To increase the production, the optimal environmental conditions for microalgae are required. Light intensity is one of the important factors that significantly affects the biomass and pigment of microalgae. The study aimed to determine the effect of light intensity (1,500; 3,000; and 4,500 lux) on growth, biomass production, chlorophyll-a, and carotenoid content of Nannochloropsis sp. strain BJ17. The results showed that different light intensities significantly affected the growth, biomass, chlorophyll-a and carotenoid contents of Nannochloropsis sp. strain BJ17. Increasing light intensity resulted in the increase of the growth rate, biomass, chlorophyll-a, and carotenoid contents of Nannochloropsis sp. strain BJ17. The cell achieved the highest specific growth rate of 1.729 /day and the cell concentration of $43.333 \times 10^{6} \mathrm{cell} / \mathrm{mL}$ at a light intensity of 4,500 lux. The highest chlorophyll-a and carotenoid concentrations of algae were obtained at $4,500 \operatorname{lux}(8.304 \mu \mathrm{g} / \mathrm{mL}$ and $3.892 \mu \mathrm{g} / \mathrm{mL}$, respectively). This study suggested that increasing light intensity led to the increase in the growth, biomass, chlorophyll-a, and carotenoid content of Nannochloropsis sp. strain BJ17.
\end{abstract}

Keywords: carotenoid, chlorophyll, biomass, growth rate, light intensity

\begin{abstract}
ABSTRAK
Nannochloropsis sp. diketahui sebagai sumber pakan alami dan pigmen pada budidaya perikanan. Budidaya pada kondisi lingkungan yang optimal diperlukan untuk meningkatkan produksi mikroalga. Intensitas cahaya merupakan salah satu faktor esensial yang secara signifikan mempengaruhi biomassa dan pigmen mikroalga. Tujuan penelitian ini adalah untuk menentukan pengaruh intensitas cahaya yang berbeda (1.500, 3.000, and 4.500 lux) terhadap pertumbuhan, produksi biomassa, klorofil-a, dan karotenoid Nannochloropsis sp. strain BJ17. Hasil menunjukkan bahwa intensitas cahaya yang berbeda berpengaruh secara signifikan terhadap pertumbuhan, biomassa dan klorofil-a dan karotenoid Nannochloropsis sp. strain BJ17. Semakin tinggi intensitas cahaya maka laju pertumbuhan, biomassa, kandungan klorofil-a dan total karotenoid Nannochloropsis sp. strain BJ17 semakin

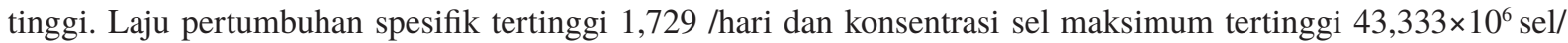
$\mathrm{mL}$ dihasilkan pada intensitas cahaya 4.500 lux. Konsentrasi klorofil-a $(8,304 \mu \mathrm{g} / \mathrm{mL})$ dan karotenoid $(3,892$ $\mu \mathrm{g} / \mathrm{mL}$ ) tertinggi juga diperoleh pada intensitas cahaya 4.500 lux. Studi ini menunjukkan bahwa peningkatan intensitas cahaya berperan dalam meningkatkan pertumbuhan, produksi biomassa, klorofil-a, dan karotenoid Nannochloropsis sp. strain BJ17.
\end{abstract}

Kata kunci: karotenoid, klorofil, biomassa, pertumbuhan, intensitas cahaya

\section{INTRODUCTION}

Microalgae is a photosynthetic organism with a rapid growth rate and capable of converting light energy, carbon dioxide, and nutrients into biomass and generating essential pigment (Mata et al., 2010). Chlorophyll and carotenoids are essential, dominant pigment in microalgae (Koller et al.,
2014) that have antioxidant properties (Cardozo et al., 2007) and pharmaceutical application (Koller et al., 2014). Furthermore, the carotenoids are also used as micro-ingredients in aquaculture feed (Yaakob et al., 2014).

Nannochloropsis sp. is microalgae that has been widely used as a live feed in aquaculture (Camacho-Rodríguez et al., 2013; Freire et al., 
2016). It is also known as potential producers of pigments such as chlorophyll and carotenoids (Lubian et al., 2000; Hosikian et al., 2010).

Microalgae biomass and pigment production vary depending on culture conditions (Rao et $a l .$, 2007), such as photoperiod, temperature and light intensity (Kitaya et al., 2008; Fakhri et al., 2015). Environmental adjustment can effectively optimize the growth rate of macroalgae (Mata $e t$ al., 2010). Moreover, light intensity affects the physiology of microalgae (Khoeyi et al., 2012). Photoautotrophic culture and the intensity of light are essential factors, which determine growth rate and biomass production of microalgae. Light intensity also affects the metabolism and pigment composition of microalgae (Sánchez-Saavedra \& Voltolina, 1996). In response to the increase or reduction of light intensity, the pigments contents of microalgae may be altered (Sánchez-Saavedra \& Voltolina, 2002).

The effect of light intensity on Nannochloropsis sp. growth has been previously studied (Wahidin et al., 2013; Probir et al., 2011). However, information related to the effect of light intensity on pigment contents (chlorophyll and carotenoid) of Nannochloropsis sp. is still limited. Furthermore, algae growth varies depending on the species (species-specific) (Banerjee et $a l ., 2011)$. This study aimed to determine the optimum light intensity for the growth, biomass and pigment production of Nannochloropsis sp. BJ17 strain. This study can also be applied to evaluate the potential Nannochloropsis sp. BJ17 strain to generate chlorophyll and carotenoids.

\section{MATERIALS AND METHODS}

\section{Strain and growth medium of Nannochloropsis sp. strain BJ17}

Nannochloropsis sp. BJ17 strains were obtained from Brackish Water Aquaculture Institute of Jepara, Central Java. These strains can rapidly growth in a wide range of salinity. Walne medium, which contained $100 \mathrm{~g} / \mathrm{L} \mathrm{NH}_{4} \mathrm{NO}_{3} ; 20$ $\mathrm{g} \mathrm{NaH}_{2} \mathrm{PO}_{4} ; 33.6 \mathrm{~g} \mathrm{H}_{3} \mathrm{BO}_{3} ; 0.36 \mathrm{~g} \mathrm{MnCl}_{2} ; 1.3 \mathrm{~g}$ $\mathrm{FeCl}_{2} ; 45.0 \mathrm{~g} \mathrm{EDTA} / \mathrm{L}$ and $12.01 \mathrm{~g} / \mathrm{L}$ vitamin $\mathrm{B} 12$, was used as medium with seawater. Walne and vitamin dose of fertilizer were $1 \mathrm{~mL} / \mathrm{L}$ and $0.5 \mathrm{~mL} / \mathrm{L}$, respectively.

\section{Nannochloropsis sp. BJ17 stock culture conditions}

Nannochloropsis sp. BJ17 culture in exponential phase was used as an inoculant.
The inoculant was then cultivated in $500 \mathrm{~mL}$ erlenmeyer. A total volume of media and inoculant was $350 \mathrm{~mL}$. The cultures were incubated under continuous light 24:0 (light:dark cycle). The incubation conditions used were $29 \pm 2{ }^{\circ} \mathrm{C}$, the salinity of $15 \mathrm{~g} / \mathrm{L}$, the light intensity of 3,000 lux, and continuous aeration for four days (Fakhri et al., 2015).

\section{Culture treatments}

The light intensity treatments (in lux) were 1,500; 3,000; and 4,500 with three replicates per light intensity treatment. Microalgae biomass was harvested after six days of culture, and used for biomass and pigment analyses.

Nannochloropsis sp. BJ17 was used as inoculants at the exponential phase or four-dayold cultures. The inoculant was cultured into a 2.5 $\mathrm{L}$ container with a total volume of $1.5 \mathrm{~L}$ seawater with $15 \mathrm{~g} / \mathrm{L}$ salinity. Initial cell concentration for all treatments was $5.5 \times 10^{5}$ cells $/ \mathrm{mL}$. Microalgae cells were cultured at $28^{\circ} \mathrm{C}$, with photoperiod 24 : 0 and continuously aerated.

\section{Analysis of growth}

Microalgae growth was observed using cells concentration calculation method with $0.1 \mathrm{~mm}$ deep Neubauer haemocytometer (BOECO, Hamburg, Germany). Specific growth rate $(\mu)$ was calculated using the following formula (Fogg \& Thake, 1987) :

$$
\mu(/ \text { day })=\frac{\ln \left(\mathrm{x}_{2}\right)-\ln \left(\mathrm{x}_{1}\right)}{\mathrm{t}_{2}-\mathrm{t}_{1}}
$$

Note:

$\mu=$ growth rate of per unit cell concentration

$\mathrm{x}_{1}=$ cell concentration at time 1

$\mathrm{x}_{2}=$ cell concentration at time 2

$\mathrm{t}_{1}=$ time 1

$\mathrm{t}_{2}=$ time 2

Cell doubling time (td) is the average generation time required for cell to double in concentration. Doubling time can be calculated using the formula (Ak et al., 2008):

$$
\operatorname{td}(\text { day })=\frac{\ln 2}{\mu}=\frac{0,693}{\mu}
$$

\section{Biomass analysis}

The cell biomass of Nannochloropsis sp. BJ17 strains were analyzed following the method of Janssen (2002). Microalgae samples were taken 
at the day- 6 of microalgae growth. The filter paper $\mathrm{GF} / \mathrm{C}$ (diameter $90 \mathrm{~mm}$ ) were dried at $105{ }^{\circ} \mathrm{C}$ for $2 \mathrm{~h}$ until the weight is constant [A]. $25 \mathrm{~mL}$ of microalgae suspension was filtered through a filter paper GF/C, and washed with 25 $\mathrm{mL}$ of fresh water to avoid contamination with the insoluble salt in the media. The filter paper was placed in an oven at $105^{\circ} \mathrm{C}$ for $2 \mathrm{~h}$ until the weight is constant. The filter paper was placed in a desiccator, and re-weighed [B]. The calculation used equation below:

Dry weight/biomass $(\mathrm{mg} / \mathrm{L})$

$$
=\frac{[\mathrm{B}]-[\mathrm{A}]}{\text { sample volume }} \times 1,000
$$

Note:

$\mathrm{A}=$ filter paper weight

$\mathrm{B}=$ filter paper weight + algae

\section{Chlorophyll-a and carotenoids analysis}

In this study, chlorophyll-a and carotenoids were analyzed using methanol extraction method (Ritchie, 2006). $10 \mathrm{~mL}$ of microalgae samples were centrifuged at $6,000 \mathrm{rpm}$ for $10 \mathrm{~min} .10 \mathrm{~mL}$ of absolute methanol was added to the centrifuged and vortexed pellet. Tube wrapped in aluminum foil and the mixture (pellet and solvent) was put in a water bath at a temperature of $70{ }^{\circ} \mathrm{C}$ for 10 min. The sample was vortexed and centrifuged at $6,000 \mathrm{rpm}$ for $10 \mathrm{~min}$. The clear supernatant was measured at the wavelengths of 480,652 , and $665 \mathrm{~nm}$ using a spectrophotometer (Spectroquant Pharo 300, Merck Millipore).
The content of chlorophyll-a was calculated using the method of Ritchie (2006), and total carotenoids were calculated following the method of Kim et al. (2014).

$$
\begin{aligned}
& \text { Chlorophyll-a }(\mu \mathrm{g} / \mathrm{mL}) \\
& =16,5169 \times \mathrm{A}_{665}-8,0962 \times \mathrm{A}_{652} \\
& \text { Total carotenoid }(\mu \mathrm{g} / \mathrm{mL}) \\
& =4 \times \mathrm{A}_{480}
\end{aligned}
$$

\section{Statistical analysis}

Statistical analysis was performed using SPSS 16.0. Growth, biomass, chlorophyll-a and carotenoids data were analyzed by analysis of variance (ANOVA) test with $95 \%$ confidence. To determine the relationship between the light intensity and growth rate and biomass, regression analysis was carried out.

\section{RESULTS AND DISCUSSION}

\section{Growth and biomass of Nannochloropsis sp. strain BJ17}

The growth of Nannochloropsis sp. BJ17 strain cells under different light intensities $(1,500$; 3,000; and 4,500 lux) is illustrated in Figure 1. The results showed that similar growth pattern was found in cultured cells under different light intensities. The maximum specific growth rate occurred between day-2 and day- 1 . The highest cell concentration was achieved at day- 6 . In addition, cell growth curve did not show a lag phase on all treatments, and microalgae growth

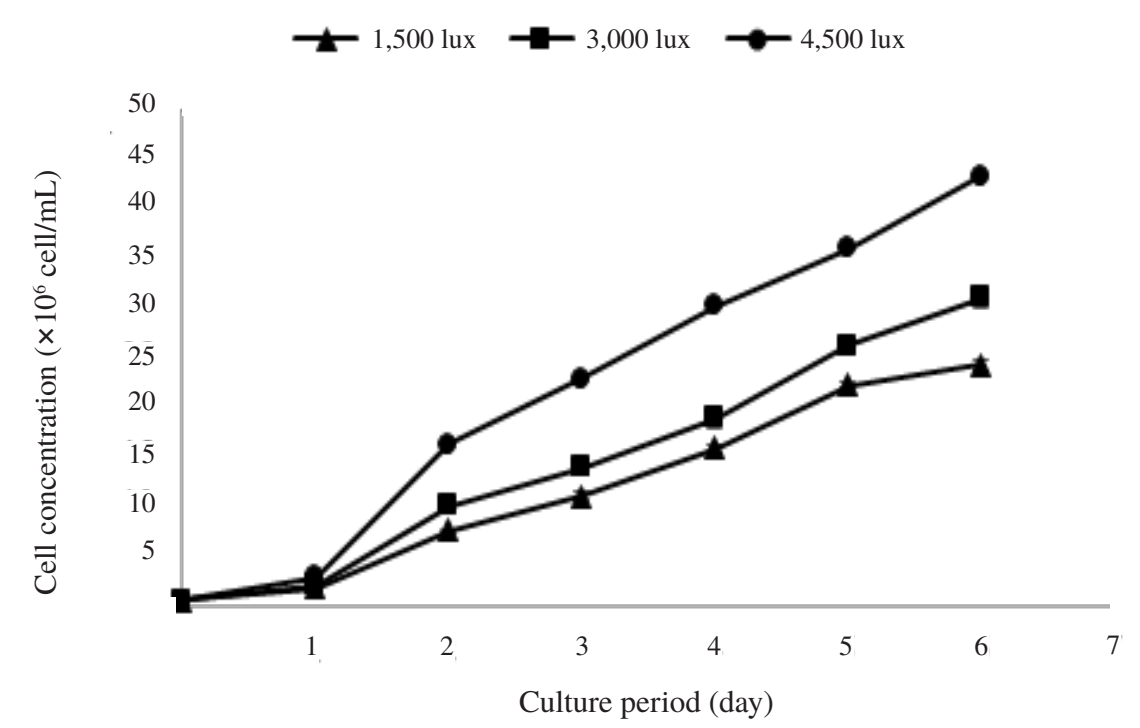

Figure 1. Growth of Nannochloropsis sp. BJ17 strain under different light intensities (1,500; 3,000; and 4,500 lux) for six days of culture period. 
achieved rapid logarithmic phase. Similarly, Sforza et al. (2014) reported that the microalgae, Scenedesmus obliquus do not experience lag phase when they were treated with different light intensities. This indicates that some species of microalgae can grow in different conditions of light intensity without experiencing stress.

Table 1 shows that different light intensities have a significant $(\mathrm{P}<0.05)$ effect on the specific growth rate, doubling time, maximum cell concentration and biomass of Nannochloropsis sp. BJ17 strain. The highest specific growth rate was 1.73 day $(\mathrm{P}<0.05)$ with a doubling time about 0.401 days or $9.62 \mathrm{~h}$. The highest cell concentration of $43.3 \times 10^{6}$ cells $/ \mathrm{mL} \quad(\mathrm{P}<0.05)$ was obtained at 4,500 lux of light intensity, while the highest biomass of $0.824 \mathrm{~g} / \mathrm{L}(\mathrm{P}<0.05)$ was resulted from 4,500 lux of light intensity.

Figure 2 shows the relationship between the light intensity and the growth rate generates a linear pattern with the equation of $\mathrm{y}=0.0001 \mathrm{x}$ +1.2761 and $R^{2}=0.901$. Figure 3 shows the relationship between the light intensity and biomass, which generate a linear pattern with the equation of $y=0,0002 x+0.1893$ and $R^{2}=0.985$. The results indicate that the increase in light intensity can accelerate growth rate and biomass of Nannochloropsis sp. BJ17 strain.

Imaizumi et al. (2014) reported that the culture of Chlorella zofingiensis with light intensity between 75,150 , and $250 \mu \mathrm{mol}$ photon/ $\mathrm{m}^{2} / \mathrm{sec}$ produced specific growth rate between $0.399 /$ day, $0.490 /$ day, and 0,700/day, respectively. Furthermore, the increase in the light intensity from $75 \mu \mathrm{mol}$ photons $/ \mathrm{m}^{2} / \mathrm{s}$ to $250 \mu \mathrm{mol}$ photon/ $\mathrm{m}^{2} / \mathrm{sec}$ amplified the maximum cell concentration of $C$. Zofingiensis (Imaizumi et al., 2014). The result showed that the growth rate and cell concentration increases with increasing light intensity. Nonetheless, the growth significantly decreased in lower light intensities. Additionally, Wahidin et al. (2013) reported that the increase in the light intensity from $50 \mu \mathrm{mol}$ photon/ $\mathrm{m}^{2} / \mathrm{s}$ to $100 \mu \mathrm{mol}$ photons $/ \mathrm{m}^{2} / \mathrm{s}$ boosted the

Table 1. Specific growth rate, doubling time, maximum cell concentration and biomass of Nannochloropsis sp. BJ17 strain under different light intensities

\begin{tabular}{lrrr}
\hline \multicolumn{1}{c}{ Parameters } & \multicolumn{3}{c}{ Light intensities (lux) } \\
\cline { 2 - 4 } & \multicolumn{1}{c}{1,500} & \multicolumn{1}{c}{3,000} & 4,500 \\
\hline Specific growth rate (/day) & $1.431 \pm 0.038 \mathrm{a}$ & $1.561 \pm 0.055 \mathrm{~b}$ & $1.729 \pm 0.048 \mathrm{c}$ \\
Doubling time (day) & $0.484 \pm 0.013 \mathrm{a}$ & $0.444 \pm 0.015 \mathrm{~b}$ & $0.400 \pm 0.011 \mathrm{c}$ \\
Maximum cell concentration $\left(\times 10^{6} \mathrm{cell} / \mathrm{mL}\right)$ & $24.333 \pm 0.577 \mathrm{a}$ & $31.133 \pm 0.981 \mathrm{~b}$ & $43.333 \pm 1.433 \mathrm{c}$ \\
Biomass $(\mathrm{g} / \mathrm{L})$ & $0.434 \pm 0.022 \mathrm{a}$ & $0.620 \pm 0.004 \mathrm{~b}$ & $0.824 \pm 0.008 \mathrm{c}$ \\
\hline
\end{tabular}

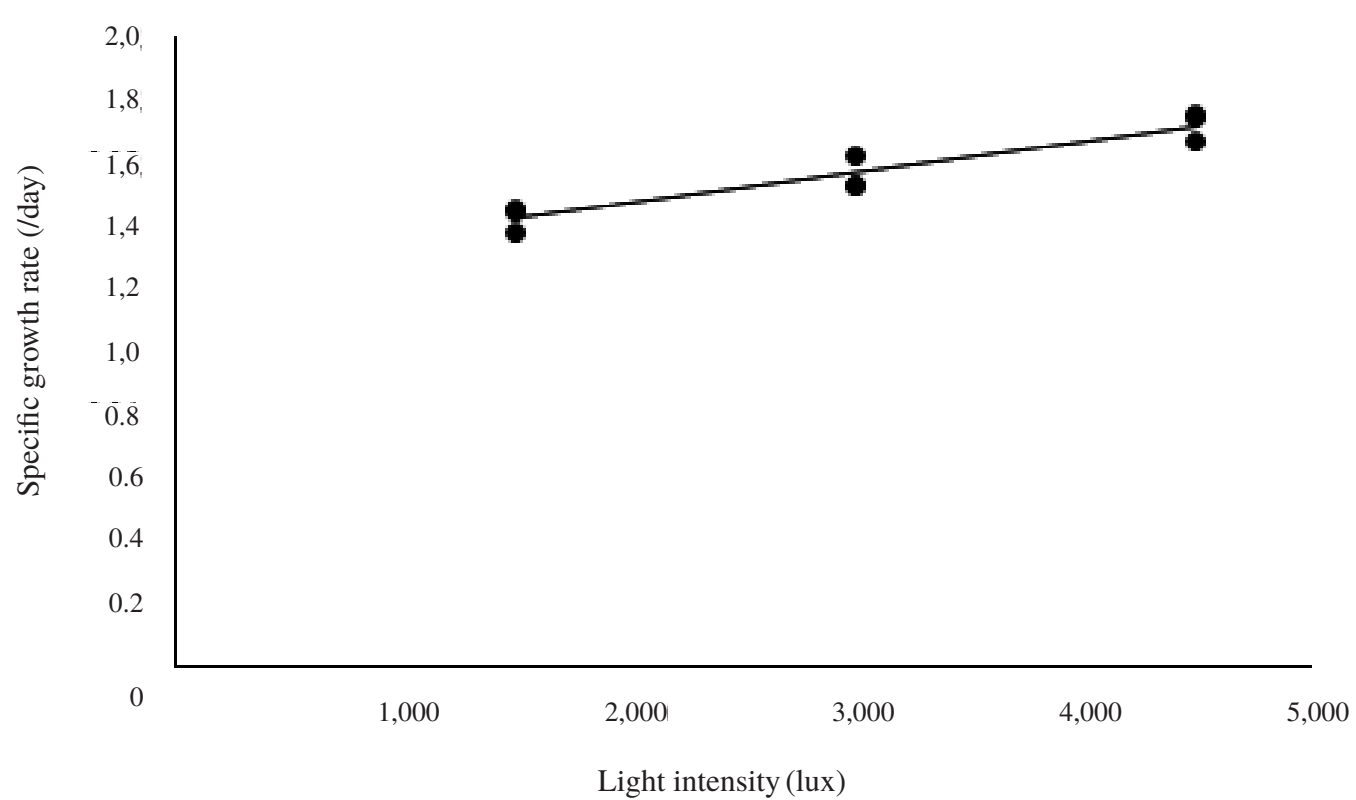

Figure 2. Regression analysis between the light intensity and the specific growth rate of Nannochloropsis sp. strain BJ17. 
specific growth rate and the maximum cell concentration of Nannochloropsis sp. The growth rate of Nannochloropsis sp. BJ17 strain in the present study was higher than the growth rate of Nannochloropsis sp. in the previous study (Wahidin et al., 2013). Solovchenko (2008) stated that the maximum biomass of $8 \mathrm{mg} / \mathrm{mL}$ resulted from light intensity of $400 \mu \mathrm{mol}$ photon $/ \mathrm{m}^{2} / \mathrm{s}$ and biomass production decreased at $4.2 \mathrm{mg} / \mathrm{mL}$ at 35 $\mu \mathrm{mol}$ photon $/ \mathrm{m}^{2} / \mathrm{s}$ light intensity.

George et al. (2014) described that light is an essential parameter that becomes the limiting factor for Ankistrodesmus falcatus growth, and has been the major factor that determines the photosynthesis rate of microalgae. Similarly, Wahidin et al. (2013) reported that the light intensity controls the biomass production of photosynthetic organisms. Natural or artificial light provides the energy for the transfer of electrons from water to NADP + to form NADPH (nicotinamide adenine dinucleotide phosphate) and ATP (adenine tri-phosphate).

The content of chlorophyll-a and total carotenoids Nannochloropsis sp. strain BJ17

The chlorophyll-a and total carotenoid contents of Nannochloropsis sp. BJ17 strain under different light intensities are presented in Table 2. Differences in light intensity significantly affected the chlorophyll-a and total carotenoid contents of Nannochloropsis sp. BJ17 strain $(\mathrm{P}<0.05)$. Increasing the light intensity resulted in increased contents of chlorophyll-a and total carotenoid of Nannochloropsis sp. BJ17 strain. The highest chlorophyll-a and total carotenoid contents of Nannochloropsis sp. BJ17 strain were $8.304 \mathrm{mg} /$ $\mathrm{mL}$ and $3.892 \mathrm{mg} / \mathrm{mL}$, respectively, generated at 4,500 lux $(\mathrm{P}<0.05)$ (Table 2). These results were consistent with George et al. (2014) who reported an increase in the chlorophyll content of A. falcatus from $10.29 \mathrm{mg} / \mathrm{mL}$ (light intensity of $30 \mu \mathrm{mol}$ photon $/ \mathrm{m} 2 / \mathrm{s}$ ) to $11.73 \mu \mathrm{g} / \mathrm{mL}$ when they were cultured in $150 \mu \mathrm{mol}$ photon $/ \mathrm{m} 2 / \mathrm{s}$ of light intensity. A similar increase in chlorophyll was also found in Chlorella sp. (Cheirsilp \& Torpee, 2012). Moreover, Junior et al. (2007) stated that the chlorophyll content was correlated with the concentration of microalgae cells. The higher concentration of chlorophyll cells, the greater values of chlorophyll produced.

George et al. (2014) illustrated that the carotenoid content of $A$. falcatus increased due

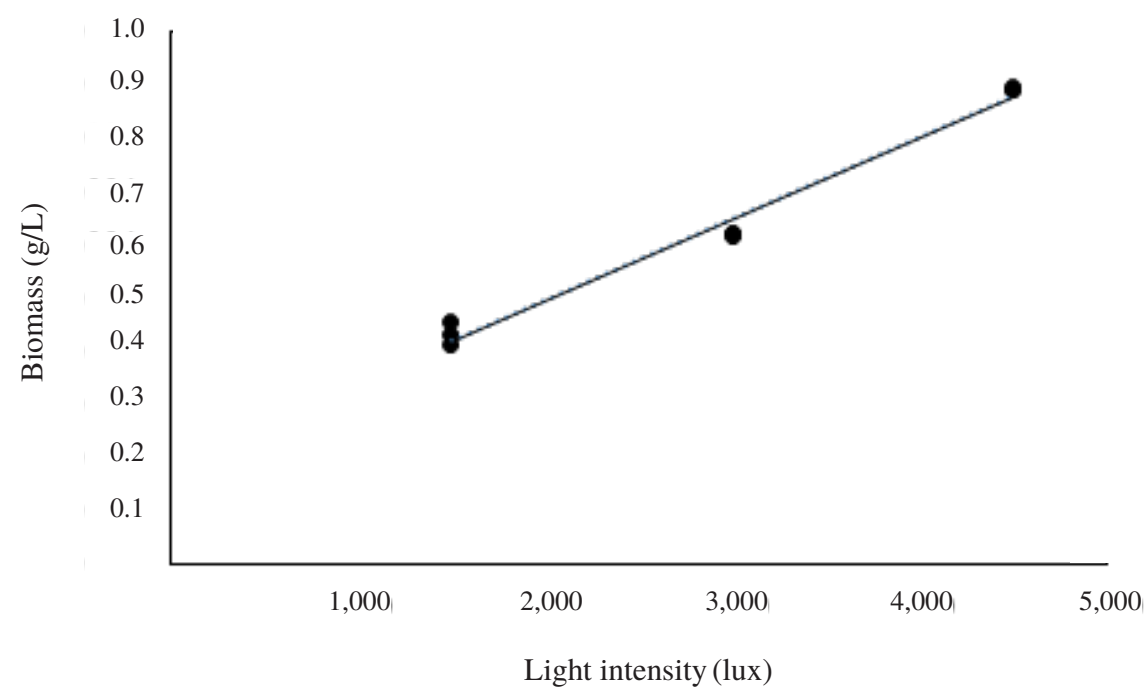

Figure 3. Regression analysis between the light intensity and biomass of Nannochloropsis sp. strain BJ17.

Table 2. The chlorophyll-a content and carotenoids of Nannochloropsis sp. BJ17 strain under different light intensities

\begin{tabular}{lccc}
\hline \multirow{2}{*}{\multicolumn{1}{c}{ Parameters }} & \multicolumn{3}{c}{ Light intensities (lux) } \\
\cline { 2 - 4 } & 1,500 & 3,000 & 4,500 \\
\hline Chlorophyll-a $(\mu \mathrm{g} / \mathrm{mL})$ & $4.977 \pm 0.095 \mathrm{a}$ & $6.520 \pm 0.049 \mathrm{~b}$ & $8.304 \pm 0.248 \mathrm{c}$ \\
Carotenoid $(\mu \mathrm{g} / \mathrm{mL})$ & $2.830 \pm 0.014 \mathrm{a}$ & $3.518 \pm 0.018 \mathrm{~b}$ & $3.892 \pm 0.016 \mathrm{c}$ \\
\hline
\end{tabular}


to increased exposure to light. This is most likely as a mechanism of adaptation to high light intensity. Also, Richardson et al. (1983) reported pigment content and photosynthetic activity of microalgae cultured significantly changed due to differences in light intensities. In addition, Kumar et al. (2011) reported that Spirulina platensis carotenoid content increased with increasing light. This is a form of adaptation mechanisms of microalgae for photo-protection.

Chlorophyll-a and carotenoid contents of Nannochloropsis sp. BJ17 strain were respectively $36 \%$ and $11 \%$ higher than chlorophyll-a and carotenoid contents of Chlorella sp. (Fathi \& Asem, 2013). In addition, the carotenoid content of Nannochloropsis sp. BJ17 strain was higher than the carotenoid content of A. falcatus cultured in bold basal medium, CHU-10 and Zarrouk Medium (George et al., 2014). The results suggested that Nannochloropsis sp. BJ17 strain is a potential source of chlorophyll-a pigment and carotenoids.

\section{CONCLUSION}

The results showed that the different light intensities significantly affected the growth, biomass and chlorophyll-a and total carotenoids of Nannochloropsis sp. BJ17 strain. Furthermore, the higher of light intensity exposed to Nannochloropsis sp. BJ17 strain, the growth rate, biomass, chlorophyll-a, and carotenoids of Nannochloropsis sp. BJ17 strain were also increased.

\section{ACKNOWLEDGEMENTS}

We would like to thank the Faculty of Fisheries and Marine Sciences, Brawijaya University, for providing the fund, which allowed us to undertake the research.

\section{REFERENCES}

Ak I, Cirik S, Goksan T. 2008. Effect of light intensity, salinity, and temperature on growth in Camalt1 strain of Dunaliella viridis Teodoresco from Turkey. Journal of Biological Sciences 8: 1356-1359.

Banerjee S, Hew WE, Khatoon H, Shariff M, Yusoff FM. 2011. Growth and proximate composition of tropical marine Chaetoceros calcitrans and Nannochloropsis oculata cultured outdoors and under laboratory conditions. African Journal of Biotechnology 10: 1375-1383.

Camacho-Rodríguez J, Cerón-García MC, González-López CV, Fernández-Sevilla JM, Contreras-Gómez A, Molina-Grima E. 2013. A low-cost culture medium for the production of Nannochloropsis gaditana biomass optimized for aquaculture. Bioresource Technology 144: 57-66.

Cardozo KH, Guaratini T, Barros MP, Falcão VR, Tonon AP, Lopes NP, Campos S, Torres MA, Souza AO, Colepicolo P, Pinto E. 2007. Metabolites from algae with economical impact. Comparative Biochemistry and Physiology 146: 60-78.

Cheirsilp B, Torpee S. 2012. Enhanced growth and lipid production of microalgae under mixotrophic culture condition: Effect of light intensity, glucose concentration and fed-batch cultivation. Bioresource Technology 110: 510-516.

Fakhri M, Arifin NB, Budianto B, Yuniarti A, Hariati AM. 2015. Effect of salinity and photoperiod on growth of microalgae Nannochloropsis sp. and Tetraselmis sp. Nature Environment and Pollution Technology 14: 563-566.

Fathi M, Asem A. 2013. Investigating the impact of $\mathrm{NaCl}$ salinity on growth, $\beta$-carotene, and chlorophyll a in the content life of halophytes of algae Chlorella sp. AACL Bioflux 6: 241245.

Fogg GE, Thake B. 1987. Algae Cultures and Phytoplankton Ecology, $3^{\text {rd }}$ ed. Wisconsins, United States: The University of Wisconsins Press.

Freire I, Cortina-Burgueño A, Grillea P, Arizcun MA, Abellán, E, Segura M, Sousa FW, Otero, A. 2016. Nannochloropsis limnetica: A freshwater microalga for marine aquaculture. Aquaculture 459: 124-130.

George B, Pancha I, Desai C, Chokshi K, Paliwal C, Ghosh T, Mishra S. 2014. Effects of different media composition, light intensity and photoperiod on morphology and physiology of freshwater microalgae Ankistrodesmus falcatus - A potential strain for bio-fuel production. Bioresource Technology 171: 367-374.

Hosikian A, Lim S, Halim R, Danquah MK. 2010. Chlorophyll extraction from microalgae: A review on the process engineering aspects. International Journal of Chemical Engineering 1: $1-11$. 
Imaizumi Y, Nagao N, Yusoff FMD., Taguchi S, Toda T. 2014. Estimation of optimum specific light intensity per cell on a high-cell-density continuous culture of Chlorella zofingiensis not limited by nutrients or $\mathrm{CO}_{2}$. Bioresource Technology 162: 53-59.

Janssen MGJ. 2002. Cultivation of microalgae: Effect of light/dark cycles on biomass yield [Thesis]. Netherland: Wageningen University.

Junior AMM, Neto EB, Koening ML, Leça EE. 2007. Chemical compositon of three microalgae species for possible use in mariculture. Brazilian Archives of Biology and Technology 50: 461-467.

Khoeyi ZA, Seyfabadi J, Ramezanpour Z. 2012. Effect of light intensity and photoperiod on biomass and fatty acid composition of the microalgae Chlorella vulgaris. Aquaculture International 20: 41-49.

Kim CW, Sung MG, Nam K, Moon M, Kwon JH, and Yang JW. 2014. Effect of monochromatic illumination on lipid accumulation of Nannochloropsis gaditana under continuous cultivation. Bioresource Technology 159: 30-35.

Kitaya Y, Xiao L, Masuda A, Ozawa T, Tsuda M, Omasa K. 2008. Effects of temperature, photosynthesis photon flux density, photoperiod and $\mathrm{O}_{2}$ and $\mathrm{CO}_{2}$ concentrations on growth rates of the symbiotic Dinoflagellate, Amphidinium sp. Journal of Applied Phycology 20: 287-292.

Koller M, Muhr A, Braunegg G. 2014. Microalgae as versatile cellular factories for valued products. Algal Research 6: 52-63.

Kumar M, Kulshreshtha J, Singh GP. 2011. Growth and biopigment accumulation of cyanobacterium Spirulina platensis at different light intensities and temperature. Brazilian Journal of Microbiology 42: 1128-1135.

Lubian LM, Montero O, Moreno-Garrido I, Huertas IE, Sobrino C, Gonzalez-del Valle M, Pares, G. 2000. Nannochloropsis (Eustigmatophyceae) as source of commercially valuable pigments. Journal of Applied Phycology 12: 249-255.

Mata MT, Martins AA, Caetano, N.S. 2010. Microalgae for biodiesel production and other applications: a review. Renewable Sustainable Energy Reviews 14: 217-232.
Parmar A, Singh NK, Pandey A, Gnansounou E, Madamwar D. 2011. Cyanobacteria and microalgae: a positive prospect for biofuels. Bioresource Technology 102: 10163-10172.

Probir D, Lei W, Siti SA, Jeffrey PO. 2011. Enhanced algae growth in both phototrophic and mixotrophic culture under blue light. Bioresource Technology 102: 3883-3887.

Rao AR, Dayananda C, Sarada R, Shamala TR, Ravishankar, GA. 2007. Effect of salinity on growth of green alga Botryococcus braunii and its constituents. Bioresource Technology 98: 560-564.

Richardson K, Beardall J, Raven, JA. 1983. Adaptation of unicellular algae to irradiance: an analysis of strategies. New Phytologist 93: 157-191.

Ritchie R. 2006. Consistent sets of spectrophotometric chlorophyll equations for acetone, methanol and ethanol solvents. Photosynthesis Research 89: 27-41.

Sánchez-Saavedra MP, Voltolina D. 1996. Effect of blue-green light on growth rate and chemical composition of three diatoms. Journal of Applied Phycology 8: 131-137.

Sánchez-Saavedra MP, Voltolina D. 2002. Effect of photon fluence rates of white and bluegreen light on growth efficiency and pigment content of three diatoms species in batch cultures. Ciencias Marinas 28: 273-279.

Sforza E, Gris B, De-Farias Silva CE, Morosinotto T, Bertucco A. 2014. Effects of light on cultivation of Scenedesmus obliquus in batch and continuous flat plate photobioreactor. Chemical Engineering Transactions 38: 211216.

Solovchenko AE, Khozin-Goldberg I, Didi-Cohen S, Cohen Z, Merzlyak MN. 2008. Effects of light intensity and nitrogen starvation on growth, total fatty acids and arachidonic acid in the green microalga Parietochloris incisa. Journal of Applied Phycology 20: 245-251

Wahidin S, Idris A, Shaleh SRM. 2013. The influence of light intensity and photoperiod on the growth and lipid content of microalgae Nannochloropsis sp. Bioresource Technology 129: 7-11.

Yaakob Z, Ali E, Zainal A, Mohamad M, Takriff MS. 2014. An overview: biomolecules from microalgae for animal feed and aquaculture. 